\title{
Bioprospecting thermophilic glycosyl hydrolases, from hot springs of Himachal Pradesh, for biomass valorization
}

\author{
Sugitha Thankappan ${ }^{1}$, Sujatha Kandasamy ${ }^{1}$, Beslin Joshi ${ }^{1}$, Ksenia N. Sorokina², Oxana P. Taran² \\ and Sivakumar Uthandi ${ }^{* *}$ (B)
}

\begin{abstract}
The harnessing of biocatalysts from extreme environment hot spring niche for biomass conversion is significant and promising owing to the special characteristics of extremozymes attributed by intriguing biogeochemistry and extreme conditions of these environments. Hence, in the present study 38 bacterial isolates obtained from hot springs of Manikaran $\left(\sim 95^{\circ} \mathrm{C}\right)$, Kalath $\left(\sim 50^{\circ} \mathrm{C}\right)$ and Vasist $\left(\sim 65^{\circ} \mathrm{C}\right)$ of Himachal Pradesh were screened for glycosyl hydrolases by in situ enrichment technique using lignocellulosic biomass (LCB). Based on their hydrolytic potential 5 isolates were selected and they were Bacillus tequilensis VCB1, VCB2 and VSDB4), and B. licheniformis (KBFB2 and KBFB3). Cellulolytic activity assayed by growth under submerged fermentation showed that $B$. tequilensis VCB1 had maximum FPA activity $\left(3.38 \mathrm{IU} \mathrm{ml}^{-1}\right.$ ) in $48 \mathrm{~h}$, while B. licheniformis KBFB3 excelled for endoglucanase (EGA of $4.81 \mathrm{IU} \mathrm{ml}^{-1}$ in $24 \mathrm{~h}$ ) and cellobiase $\left(0.71 \mathrm{IU} \mathrm{ml}^{-1}\right.$ in $48 \mathrm{~h}$ ) activities. Among all the thermophilic biocatalysts evaluated, highest exoglucanase $\left(0.06 \mathrm{IU} \mathrm{ml}^{-1}\right)$ activity was observed in B. tequilensis VSDB4 while endoglucanase of B. licheniformis KBFB3 showed optimum specific activity at $\mathrm{pH} 7$ and $70^{\circ} \mathrm{C}$. Further, the presence of celS, celB and $x \ln B$ genes in the isolates suggest their possible role in biomass conversion. Protein profiling by SDS-PAGE analysis revealed that cellulase isoforms migrated with molecular masses of $75 \mathrm{kDa}$. The endoglucanase activity of promising strain $\mathrm{B}$. licheniformis KBFB3 was enhanced in the presence of $\mathrm{Ca}^{2+}$, mercaptoethanol and sodium hypochlorite whereas moderately inhibited by $\mathrm{Cu}^{2+}, \mathrm{Zn}^{2+}$, urea, $\mathrm{SDS}$ and $\mathrm{H}_{2} \mathrm{O}_{2}$. The results of this study indicate scope for the possible development of novel biocatalysts with multifunctional thermostable glycosyl hydrolases from hot springs for efficient hydrolysis of the complex lignocellulosic biomass into simple sugars and other derived bioproducts leading to biomass valorization.
\end{abstract}

Keywords: Glycosyl hydrolases, Thermophilic, Biomass, Hot springs

\section{Introduction}

Bioprospecting of biomass towards establishment of bio-refineries for augmentation of commodity chemicals and fuel generation warrants mandatory attention. Lignocellulosic (LC) biomass, locally available in plenty, requires less capital investments for bioconversion, reduces greenhouse gas emission and creates employment opportunities in rural livelihood. Almost twothird of the lignocellulosics are comprised of cellulose

\footnotetext{
*Correspondence: usivakumartnau@gmail.com

${ }^{1}$ Department of Agricultural Microbiology, Tamil Nadu Agricultural

University, Coimbatore 641003, India

Full list of author information is available at the end of the article
}

(40-50\%), hemicelluloses (25-35\%) and lignin (15-20\%). Hydrolytic enzymes are very crucial to break the complex biomass into macromolecules and then into simple sugars, towards the production of biomass-derived sugars, bioproducts and biochemicals. The total cellulase system consists of three enzymatic activities: (i) Endo- $\beta$-1,4-D-glucanase (EC 3.2.1.4) which randomly cleaves accessible intermolecular $\beta-1,4$ glycosidic bonds on the surface of cellulose. (ii) Exoglucanase (CBH, EC 3.2.1.91) that cleaves cellobiose units from both reducing and non-reducing end of cellulose chains. (iii) Finally, $\beta$-glucosidases (BG, EC 3.2.1.91) that hydrolyze the remaining glycosidic bonds to form glucose, which can 
then simultaneously or in a separate step get converted to the desired product by a fermenting biocatalyst.

Multifunctional glycosyl hydrolases (GHs) of microbial origin that possess cellulases, hemicellulases and pectinase activities is gaining importance for bio-based highvalue product generation. Bacterial GHs are more stable when compared to fungal hydrolases. Physical heterogeneity of the lignocellulosics and the complexity of the cellulase enzyme system (synergy and/or competition) impose limited substrate surfaces (Hong et al. 2007). It was noted that amidst significant progress that has been made recently towards commercialization of cellulosic ethanol, technological challenges are still remaining as a bottleneck for successful biomass deconstruction (Limayem and Ricke 2012). It is now recognized that cellulose is the rate-limiting substrate in bioethanol production and more efficient enzymes are required to overcome the cellulose recalcitrance to biodegradation. To overcome this impediment, strategies for novel biomass treatment and conversion are the need of the hour for global utilization of lignocellulosic wastes. In this context, one of the strategies could be the use of novel biocatalysts with enhanced stability and improved efficiency for biomass valorization. However, the approach demands a variety of new capabilities which could be only satisfied by microbes from extreme environments.

Thermophilic microbes can produce robust enzyme systems with high hydrolytic potential for cellulose degradation (Zambare et al. 2011). Hence, the discovery of novel thermostable enzymes with enhanced capabilities for biomass deconstruction may lead to significant improvements in integrated biomass processing value chains (Buckley and Wall 2006). The tolerance of high temperatures improves the enzyme robustness and increases the enzyme reaction rates needed for industrial-scale processes thereby decreasing the quantity of enzyme required (Blumer-Schuette et al. 2008). Other added benefits of thermophilic biocatalysts include reduced culture contamination, improved substrate accessibility to enzymes and a reduced viscosity of feedstock allowing the use of higher solid loadings (Kumar and Wyman 2009). Above all, the process of biomass conversion is being operated at a slightly elevated temperature of $50{ }^{\circ} \mathrm{C}$ and hence any thermophilic candidate that possesses hyper and multifunctional substrate specificity would be of greater choice. Owing to this perspective, thermophilic cellulase production has been mainly described for thermophilic microorganisms such as Clostridium sp. (Bassat and Zeikus 1981), Thermoascus aurentiacus (Tong and Cole 1982), Sporotrichum thermophile, Paenibacillus sp. (Wang et al. 2008), Brevibacillus sp. (Liang et al. 2009a), Anoxybacillus sp. (Liang et al. 2009b), Bacillus and Geobacillus (Rastogi et al. 2009). But a cocktail of biocatalysts with simultaneous production of cellulases cum xylanases are of utmost importance and ideal approach towards the simultaneous conversion of the complex cellulose and hemicelluloses to simpler sugars in biorefineries. Whereas only a few reports are available on the use of thermophilic cocktail with cellulase and xylanase for biomass conversion. In this context, the present investigation focuses on the isolation and characterization of thermophiles, from the hot springs of Himachal Pradesh, India for their biocatalytic potential for LC deconstruction using multienzyme systems and augmentation of biorefineries.

\section{Materials and methods \\ Bio-trap enrichment for isolating thermophilic GHs producing bacteria}

Thermophilic glycosyl hydrolases (GHs) producing bacteria were isolated by following bio-trap enrichment technique with various natural substrates rich in cellulose, xylan and lignin at the mouth of hot springs $\left(32^{\circ} 01^{\prime} 60 \mathrm{~N}: 77^{\circ} 20^{\prime} 60 \mathrm{E}\right)$ of Himachal Pradesh in India (Manikaran $\left(\sim 95{ }^{\circ} \mathrm{C}\right)$, Kalath $\left(\sim 50{ }^{\circ} \mathrm{C}\right)$ and Vasist $\left(\sim 65{ }^{\circ} \mathrm{C}\right)$. Perforated Falcon tubes $(15 \mathrm{ml})$ containing 200-300 mg of substrates (pine needles, para-amino benzoic acid (PABA), vanillin, acid extracted lignin, lignin extracted from black liquor, banana fibre, grapes, paddy straw, corncob and sawdust) were filled with respective thermal water, sealed, and placed in the hot springs for 10 days. The in situ enriched substrates with thermal water from hot springs were used for isolation of thermophilic cellulases and xylanase producing bacteria.

\section{Isolation and screening of $\mathrm{GHs}$ producing thermophilic biocatalysts}

Isolation of thermophilic cellulase and xylanase producing bacteria were isolated by dilution plate on Basal medium $\left(\mathrm{KH}_{2} \mathrm{PO}_{4}-2.5 \mathrm{~g}, \quad \mathrm{~K}_{2} \mathrm{HPO}_{4}-2.5 \mathrm{~g}\right.$, $\left(\mathrm{NH}_{4}\right)_{2} \mathrm{HPO}_{4}-1.0 \quad \mathrm{~g}, \quad \mathrm{MgSO} 4 \cdot 7 \mathrm{H}_{2} \mathrm{O}-0.2 \mathrm{~g}$, $\mathrm{FeSO}_{4} \cdot 7 \mathrm{H}_{2} \mathrm{O}-0.01 \mathrm{~g}, \mathrm{MnSO}_{4} \cdot 7 \mathrm{H}_{2} \mathrm{O}-0.007 \mathrm{~g}$ for $1 \mathrm{~L} \mathrm{of}$ media) supplemented with $1 \%$ carboxy methyl cellulose (CMC) for cellulolytic and $1 \%$ birch wood xylan for xylanolytic bacteria. The plates were incubated at $50{ }^{\circ} \mathrm{C}$ till sufficient isolated colonies were observed. The distinct bacterial colonies were observed for morphological and colony characteristics. After incubation, the plates were flooded with $0.1 \%$ Congo red followed by destaining with $1 \mathrm{M} \mathrm{NaCl}$ (Salem et al. 2008). Positive isolates showed a zone of clearance around the colony and the hydrolytic capacity of the bacterial isolates were calculated as given below,

$$
\text { Hydrolytic capacity }=\frac{\text { Diameter of the zone of clearance }}{\text { Diameter of the colony }}
$$


Identification of bacterial isolates by $16 \mathrm{~S}$ rDNA sequencing and phylogeny

Genomic DNA extracted from the selected bacterial isolates was used for amplification of $16 \mathrm{~S}$ rDNA gene sequences using universal primers $27 \mathrm{~F}$ ( $5^{\prime}$-AGA GTTTGATCMTGGCTCAG-3') and 1492 R ( $5^{\prime}$-ACG GCTACCTTGTTACGACTT- $3^{\prime}$ ) with the PCR conditions as follows: $95^{\circ} \mathrm{C}$ for $5 \mathrm{~min}$; 30 cycles of $94{ }^{\circ} \mathrm{C}$ for $1 \mathrm{~min}, 55^{\circ} \mathrm{C}$ for $1 \mathrm{~min}$, and $72{ }^{\circ} \mathrm{C}$ for $90 \mathrm{~s}$; and $72{ }^{\circ} \mathrm{C}$ for $10 \mathrm{~min}$ (Weisberg et al. 1991). PCR product of $1500 \mathrm{bp}$ was resolved by electrophoresis in 1.2\% agarose gel in $1 \mathrm{X}$ TAE buffer. Gels were stained with ethidium bromide $\left(10 \mathrm{mg} \mathrm{ml}^{-1}\right)$ and visualized on a gel documentation system and gel images were digitalized using a Bio-rad Gel DocXR + system (Hercules, CA, USA). The PCR products were purified using the GeneJET PCR Purification Kit (Thermo Scientific, USA) and were sequenced commercially at BioServe, India and the phylogenetic relationship was analyzed with Mega 7.0.

\section{Quantification of glycosyl hydrolases (GHs)}

The potential thermophilic isolates showing maximum cellulase and xylanase activities on plate assay were further evaluated for quantitative enzyme assays.

\section{Submerged fermentation process}

Initial inoculum for these isolates was developed using $\mathrm{LB}$ medium by overnight culture until $\mathrm{OD}_{600}$ of 0.6 and then inoculated in a volume of $50 \mathrm{~mL}$ of BPS-X production medium (Composition for $100 \mathrm{ml}: \mathrm{NaCl} 0.5 \mathrm{~g}$, K2HPO4 0.5 g, Peptone $1 \mathrm{~g}$, yeast extract $0.25 \mathrm{~g}$ at $\mathrm{pH}$ 7.0) supplemented with $1 \%$ CMC/xylan for cellulase/ xylanase production, respectively (Vincent et al. 2016). The flasks were incubated at $50{ }^{\circ} \mathrm{C}$ in an orbital shaker at $110 \mathrm{rpm}$ for $72 \mathrm{~h}$. Enzyme activity was determined at every $24 \mathrm{~h}$ intervals in triplicates using analytical grade reagents.

\section{Preparation of crude enzyme extract}

After incubation, the cultures were centrifuged at $5000 \mathrm{rpm}, 10 \mathrm{~min}$ at $4{ }^{\circ} \mathrm{C}$ and the cell-free culture supernatant was used for determination of various enzyme activities.

\section{Filter paper activity for cellulase (FPA)}

The FP activity of the crude enzyme extract was measured according to Zhang et al. (2009). One $\mathrm{ml}$ of the crude enzyme was incubated with $2 \mathrm{ml}$ of $0.1 \mathrm{M}$ citrate buffer ( $\mathrm{pH} 4.8$ ) containing $0.05 \mathrm{~g}$ Whatman No. 1 filter paper as the substrate. After incubation for $1 \mathrm{~h}$ at $50^{\circ} \mathrm{C}$, the reducing sugars in the reaction mixture were determined by the addition of $3 \mathrm{ml}$ of DNS reagent as per the method of Nelson (1944). The tubes were placed in a boiling water bath for $5 \mathrm{~min}$ and after cooling, the absorbance of the samples was measured at $540 \mathrm{~nm}$. One unit of FP activity is equivalent to one micromole of glucose liberated per $\mathrm{ml}$ of culture filtrate per minute.

\section{Endoglucanase (CMCase)}

Endoglucanase activity of the cell-free culture supernatant was determined according to Zhang et al. (2009). The supernatant containing the enzyme $(500 \mu \mathrm{l})$ was mixed with $500 \mu \mathrm{l}$ substrate (1\% CMC prepared in $50 \mathrm{mM}$ Sodium phosphate buffer, $\mathrm{pH} 7$ ) and $500 \mu \mathrm{l}$ of $50 \mathrm{mM}$ Sodium phosphate buffer $(\mathrm{pH} \mathrm{7})$ and incubated in a water bath at $50{ }^{\circ} \mathrm{C}$ for $30 \mathrm{~min}$. After incubation, the reaction was terminated by adding $3 \mathrm{ml}$ of 3, 5-dinitrosalicylic acid (DNS) reagent and the reducing sugars were estimated as previously mentioned. One unit of enzymatic activity is defined as the amount of enzyme that releases $1 \mu \mathrm{mol}$ of reducing sugars (measured as glucose) per ml per minute.

\section{Exoglucanase (Avicelase)}

Avicelase activity was determined according to Zhang et al. (2009). For exoglucanase assay, $500 \mu \mathrm{l}$ of crude enzyme was mixed with $500 \mu \mathrm{l}$ substrate $(1.25 \%$ Avicel in acetate buffer) and incubated at $50{ }^{\circ} \mathrm{C}$ for $2 \mathrm{~h}$. The reaction was terminated by submerging the tubes in an ice-cold water bath and the total soluble sugars were determined by phenol-sulfuric acid method (Dubois et al. 1956). After cooling, the absorbance of the samples was measured at $490 \mathrm{~nm}$ and the enzymatic activity of exoglucanase was defined in international units (IU). One unit of enzymatic activity is defined as the amount of enzyme that releases $1 \mu \mathrm{mol}$ of glucose equivalent per minute from Avicel.

\section{Aryl $\beta$-glucosidase (cellobiase; EC3.2.1.21)}

The aryl $\beta$-glucosidase was assayed based on chromogenic $o$-nitrophenol release from o-nitrophenyl- $\beta$-Dglucopyranoside (Wood and Bhat 1988). The reaction mixture consisted of $1.0 \mathrm{ml}$ of pNPG solution $(5 \mathrm{mM}$ in acetate buffer) and $2.0 \mathrm{ml}$ enzyme of appropriate dilution. The reaction was initiated at $50{ }^{\circ} \mathrm{C}$ for $15-30 \mathrm{~min}$ and stopped by the addition of $40.0 \mathrm{ml}$ of $\mathrm{NaOH} /$ glycine buffer $(0.4 \mathrm{M}, \mathrm{pH} 10.8)$. The absorbance of the liberated $o$-nitrophenol was measured at $425 \mathrm{~nm}$ and one unit of activity corresponding to the amount of enzyme capable of liberating 1 pmol o-nitrophenol $\mathrm{min}^{-1}$ under assay conditions. Cellobiase was determined by measuring the glucose released, by the method of Nelson (1944). 


\section{PCR screening of isolates for GHs specific genes}

The cellulolytic and xylanolytic isolates thus selected were screened for cellulase and xylanase gene using genespecific primers as given Additional file 1: Table S1 and the amplicons were resolved in $1 \%$ agarose gel.

\section{Partial purification of extracellular cellulases}

About $25 \mathrm{ml}$ of the crude enzyme solution was saturated using ammonium sulfate and the mixture was left overnight at $-40{ }^{\circ} \mathrm{C}$ for precipitation (Lee et al. 2008). The precipitates were collected by centrifugation and dissolved in $2 \mathrm{ml}$ of $0.1 \mathrm{M}$ phosphate buffer ( $\mathrm{pH}$ 7.0). The enzyme collected after ammonium sulfate precipitation was dialyzed against $0.1 \mathrm{M}$ phosphate buffer at $4{ }^{\circ} \mathrm{C}$ with three changes of buffer. The partially purified protein was assayed for enzyme activity and protein content as mentioned elsewhere.

\section{Endoglucanase activity on agarose plate}

Endoglucanase activity was confirmed on CMC (0.1\%) agarose plates as per Zhang et al. (2009). Wells were drilled in CMC agarose plates and $20 \mu \mathrm{l}$ of the partially purified enzyme was added and incubated at $50{ }^{\circ} \mathrm{C}$ for overnight. After incubation, the plates were washed with distilled water, and staining ( $0.1 \%$ congo red solution) and destaining $(1 \mathrm{M} \mathrm{NaCl})$ were performed as mentioned above to detect the hydrolytic zone (yellow halo with red background).

\section{Kinetic studies of endoglucanase}

The Michaelis-Menten kinetic model of the single-substrate reaction was investigated for the enzyme produced by the bacterial isolates. The Michaelis-Menten equation is given as follows,

$$
v=\frac{\mathrm{V}_{\max }[\mathrm{S}]}{\mathrm{K}_{m}+[\mathrm{S}]}
$$

The apparent kinetic parameters (Vmax and $\mathrm{Km}$ ) of the cellulase were determined by varying the concentration of CMC from 1 to $5 \%$ in $50 \mathrm{mM}$ citrate buffer (pH 4.5). The CMC solutions at different concentrations (1-5\%) were treated with the purified cellulase and the extent of hydrolysis was investigated. The data were analyzed using Graph Pad Prism software (version 5.0).

\section{SDS-polyacrylamide gel electrophoresis of partially purified endoglucanase and xylanase}

The protein was separated by SDS-PAGE in $12 \%$ polyacrylamide gels according to Laemmli (1970). Protein bands were detected by Coomassie-brilliant blue staining solution and destained with glacial acetic acid:methanol: water (5:45:50) and documented using Bio-rad Gel DocXR + system (Hercules, CA, USA).

\section{Native PAGE and gel diffusion assay}

The protein samples from culture supernatants were separated with a $12 \%$ Native-polyacrylamide gel electrophoresis at $4{ }^{\circ} \mathrm{C}$. Following this, the gel was placed on an agarose plate containing $0.1 \% \mathrm{CMC}$ and incubated for $1 \mathrm{~h}$, at $50{ }^{\circ} \mathrm{C}$. The plate was stained with $0.1 \%$ congo red for $30 \mathrm{~min}$ and finally washed with $1 \mathrm{M} \mathrm{NaCl}$ to detect enzyme activity (Zhang et al. 2009).

\section{Characterization of endoglucanase of $B$. licheniformis KBFB3 \\ Protein determination and specific activity}

Protein content was determined using Bradford reagent (Biorad) in a multimode microtitre plate reader (SpectraMax@i3x) with bovine serum albumin as standard at wavelength $595 \mathrm{~nm}$. The specific activity of Endoglucanase was calculated and expressed in terms of IU per mg of protein.

\section{Effect of temperature and $\mathrm{pH}$ on endoglucanase activity}

For determination of optimal temperature, the assay was carried out using $0.5 \%(\mathrm{w} / \mathrm{vol}) \mathrm{CMC}$ as a substrate in a total volume of $120 \mu \mathrm{l}$ containing $100 \mathrm{mM}$ Sodium Phosphate $(\mathrm{pH} 7.0)$. The assay mixture was incubated at $45-85{ }^{\circ} \mathrm{C}$, at $5{ }^{\circ} \mathrm{C}$ intervals for $30 \mathrm{~min}$ and the reaction was stopped by boiling for $10 \mathrm{~min}$. The free glucose released was measured as stated above.

The optimal $\mathrm{pH}$ for Endoglucanase (endoglucanase) activity was determined in various buffers with different pHs viz., Ammonium citrate buffer (3.0), Sodium acetate (4.5), Sodium Phosphate (7.0), Tris (8.5) and Ammonia buffer (9.5).

\section{Effect of metal ions on endoglucanase activity}

The effect of various metal ions on partially purified cellulase was determined by the presence of $\mathrm{NaCl}, \mathrm{KCl}$, $\mathrm{CaCl} 2, \mathrm{ZnSO} 4$ and $\mathrm{CuSO} 4$, each at $5 \mathrm{mM}$ concentration. The enzyme was incubated with different metals at $70^{\circ} \mathrm{C}$ for $1 \mathrm{~h}$ and assayed under standard assay conditions (Zhang et al. 2009). The residual endoglucanase activity was estimated against the control, in which metal ions were not present.

\section{Effect of inhibitors on endoglucanase activity}

The partially purified enzyme activity was pre-incubated with different inhibitors like ethylene diamine tetra acetic acid (EDTA), $\beta$-mercaptoethanol, dithiothreitol (DTT) and urea at a concentration of $5 \mathrm{mM}$ for $1 \mathrm{~h}$ at $70{ }^{\circ} \mathrm{C}$. The residual activity was determined under standard assay conditions. 
Table 1 Thermophilic bacterial isolates from hot springs isolated by in situ biotrap-enrichment

\begin{tabular}{ll}
\hline Substrate and location & Isolates \\
\hline Vasist & VVB1, VVB2 \\
Vanillin & VPSB1, VPSB2 \\
Paddy straw & VCRB1, VCRB2, VCRB3 \\
Crop residue & VCB1, VCB2, VCB3 \\
Corn cob & VSDB1, VSDB2, VSDB3, VSDB4 \\
Saw dust & VBFB1, VBFB2, VBFB3 \\
Banana fibre & VPB1, VPB2, VPB3 \\
Pine needle & VPAB1 \\
Para amino benzoic acid & VAB1 \\
Acid extracted lignin & VBLB1, VBLB2, VBLB3 \\
Black liquor & \\
Kalath & KBFB1, KBFB2, KBFB3 \\
Banana fibre & KGB1 \\
Grapes & \\
Manikaran & $M B B 1, M B B 2, M B B 3$ \\
Banana & MBFB1, MBFB2, MBFB3 \\
Banana fibre & MGB1, MGB2, MGB3 \\
Grapes &
\end{tabular}

Effect of surfactants and oxidizing agents on endoglucanase activity

The effects of surfactants viz., Triton $\mathrm{X} 100$, Tween80 , SDS $(0.5 \% \mathrm{v} / \mathrm{v})$, and oxidizing agents viz., $\mathrm{H}_{2} \mathrm{O}_{2}$ and sodium hypochlorite $(0.5 \% \mathrm{v} / \mathrm{v})$ were investigated in order to characterize the enzyme. The partially purified enzyme was incubated with the above-mentioned reagents for $1 \mathrm{~h}$ at $70{ }^{\circ} \mathrm{C}$ and the residual Endoglucanase activity was determined under standard assay conditions against control, in which additives was not present.

\section{Results}

Isolation and screening of cellulolytic and xylanolytic thermophilic bacteria

Screening of bacteria and assay for hydrolytic activity

Thermophilic bacteria with cellulolytic and xylanolytic activities were isolated from hot springs (Manikaran $\left(\sim 95^{\circ} \mathrm{C}\right)$, Kalath $\left(\sim 50{ }^{\circ} \mathrm{C}\right)$ and Vasist $\left.\left(\sim 65^{\circ} \mathrm{C}\right)\right)$ of Himachal Pradesh using from various lignocellulosic substrates viz., pine needles, PABA, vanillin, acid extracted lignin, lignin extracted from black liquor, banana fibre, grapes, paddy straw, crop residue, corncob and sawdust. The enrichment technique employed yielded a total of 38 isolates from the enriched samples, of which 25,4 and 9 isolates were respectively obtained from samples of Vasist, Kalath and Manikaran (Table 1; Fig. 1).

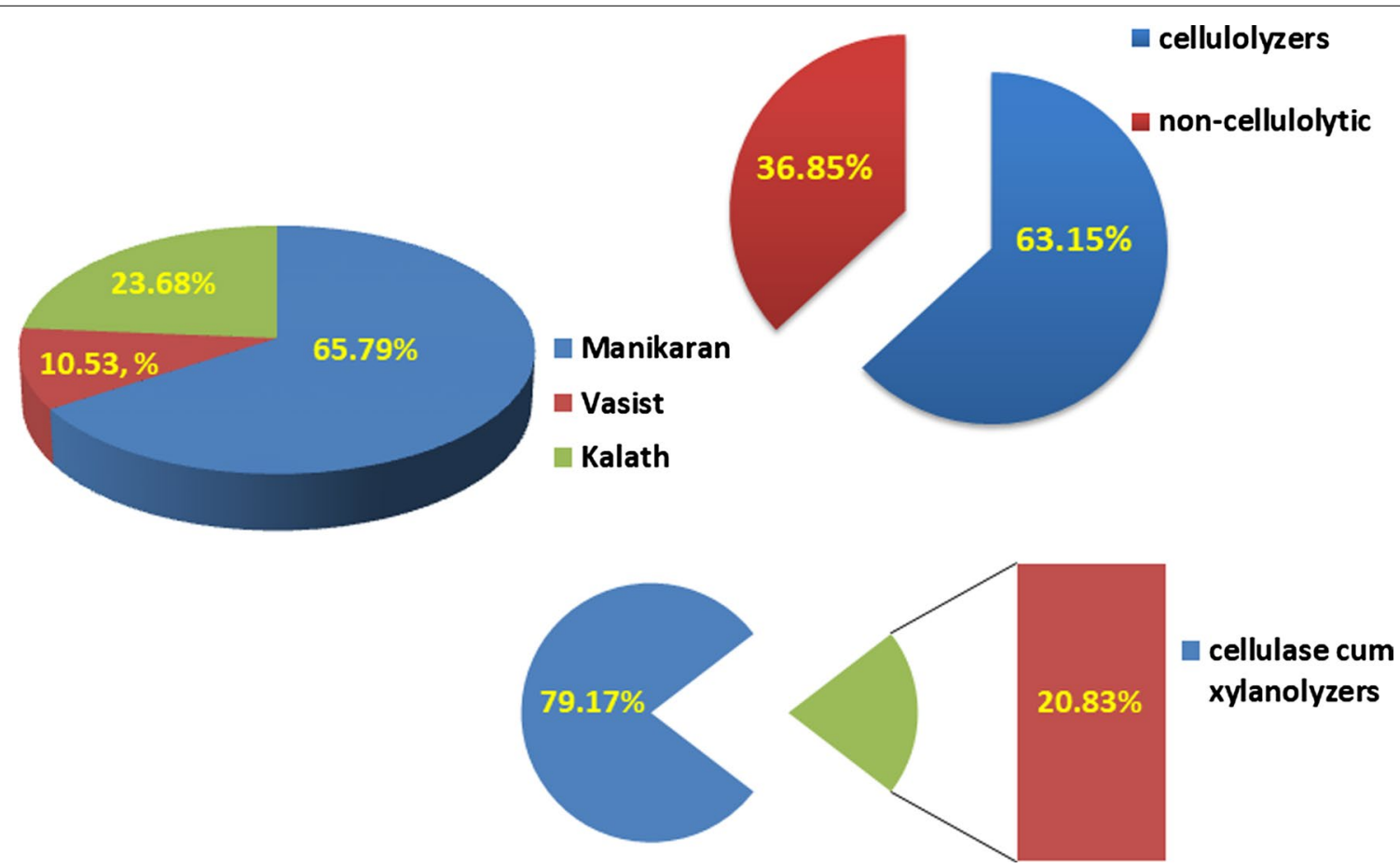

Fig. 1 Distribution of isolated thermophiles in hot springs of Himachal Pradesh. Thermophilic bacterial isolates were obtained from three hot springs Vasist, Kalath and Manikaran of Himachal Pradesh, India. The isolates were subjected to qualitative screening for cellulose utilization on CMC agar plates. Based on the hydrolytic capacity they were classified as cellulolytic and non-cellulolytic bacterial isolates 
Active digestion of cellulose and xylan by the thermophilic biocatalysts in congo red plate assays caused a halo clear zone formation indicating endoglucanase and xylanase secretion into the solid medium (Fig. 2). Among the 38 isolates, 24 isolates that showed cellulase activity at $\geq 50{ }^{\circ} \mathrm{C}$ were selected for further studies. Of the 24 cellulolytic isolates, 19 were positive for xylanase activity at $\geq 50{ }^{\circ} \mathrm{C}$. The hydrolytic capacity index $(\mathrm{HC})$ of five promising isolates VCB1, VCB2, VSDB4, KBFB3 and KBFB2 for cellulolytic and xylanolytic activities ranged between 1.46 to 4.06 and 1.67 to 5.30 respectively (Table 2 ). The maximum cellulase activity was observed with KBFB2 (4.06), while xylanase was observed with KBFB3 (5.30) followed by KBFB2 (2.60) and VCB2 (2.18).

\section{Phylogeny and identification of GHs producing thermophiles}

The promising five thermophilic isolates obtained were identified by $16 \mathrm{~S}$ rDNA gene sequence analysis. The $1.5 \mathrm{~kb}$ amplicon obtained through PCR was sequenced and further analyzed by NCBI BLAST nucleotide search and the nearest match from GenBank data was reported (Table 3 ). The phylogenetic tree constructed on the aligned datasets using neighbour joining (NJ) method using MEGA 7.0 (Fig. 3) revealed that all the isolates obtained from thermal springs were Grampositive and belong to the phylum Firmicutes. The closest phylogenetic neighbours according to the $16 \mathrm{~S}$ rDNA gene sequence data for the isolates VCB1, VCB2, and VSDB4 were Bacillus tequilensis KF054870.1 with 74 and 99\% homology, respectively. The isolates, KBFB2 and KBFB3 have a close identity with Bacillus licheniformis GQ280108.1 (99 per cent).

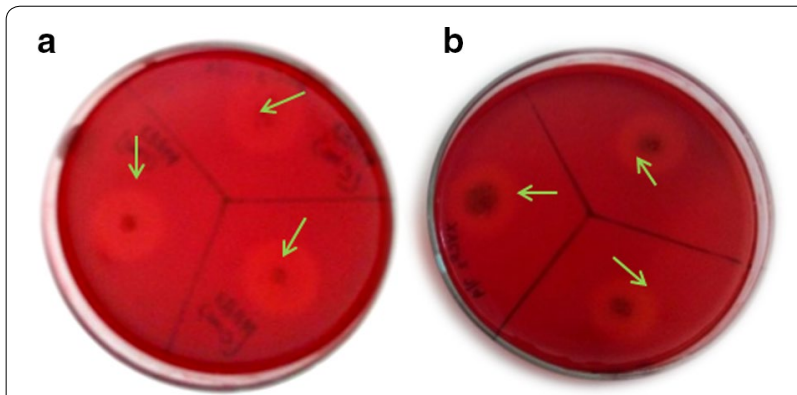

Fig. 2 a Cellulose and $\mathbf{b}$ xylan plates showing clearing zone by thermophilic bacterial isolates. The thermophilic bacterial isolates were grown on $\mathrm{CMC}$ agar and xylan agar plates respectively and incubated at $50{ }^{\circ} \mathrm{C}$ for $48 \mathrm{~h}$. The plates were flooded with $0.1 \%$ congored followed by destaining with $1 \mathrm{M} \mathrm{NaCl}$. The presence of a halo around the colonies represents hydrolytic activity, cellulolytic as well as xylanolytic respectively
Table 2 Hydrolytic capacity of the potential bacterial isolates for cellulolytic cum xylanolytic activity

\begin{tabular}{lll}
\hline Isolate & Cellulolytic activity & Xylanolytic activity \\
\hline VCB1 & $2.20 \pm 0.14^{\mathrm{a}}$ & $2.14 \pm 0.13^{\mathrm{b}}$ \\
VCB2 & $1.93 \pm 0.12^{\mathrm{a}}$ & $2.18 \pm 0.14^{\mathrm{b}}$ \\
VSDB4 & $1.46 \pm 0.09^{\mathrm{a}}$ & $1.67 \pm 0.29^{\mathrm{b}}$ \\
KBFB2 & $4.06 \pm 0.25^{\mathrm{a}}$ & $2.60 \pm 0.16^{\mathrm{b}}$ \\
KBFB3 & $3.91 \pm 0.24^{\mathrm{a}}$ & $5.30 \pm 0.33^{\mathrm{a}}$ \\
\hline
\end{tabular}

Values represent mean ( \pm standard error) $(n=3)$ and the values representing same alphabets are not significant from each other as determined by DMRT at $\mathrm{p}=0.05$

Maximum values are in italic

\section{PCR based screening of potential thermophiles} for cellulase and xylanase gene

The thermophilic biocatalysts used for enzyme assay were further confirmed by the presence of cellulase (celS and $c e l B$ and xylanase gene $(x \ln )$ using gene-specific primers. Cellulase primer $(\mathrm{CelS})$ resulted in the amplification of about $250 \mathrm{bp}$ amplicons in B. tequilensis VCB1, B. tequilensis VCB2, B. tequilensis VSDB4 and Bacillus subtilis VCB4 (positive control), while 1300 bp amplicons were observed in B. licheniformis KBFB2 and B. licheniformis KBFB3 (Fig. 4a). Moreover, amplification of cellulose binding domain resulted in $650 \mathrm{bp}$ amplicon only in two isolates, B. licheniformis KBFB2 and B. licheniformis KBFB3 (Fig. 4b) whereas, during xylanase screening, 700 bp amplicons were incurred in xylanase positive thermophilic isolates (Fig. 4c). These results confirmed the presence and role of cellulase and xylanase gene in glycosyl hydrolase activities of the thermophilic biocatalysts under study.

\section{GHs activity of thermophiles FP activity}

FPA represents total cellulase activity based on the ability to utilize filter paper and release reducing sugar

Table 3 Identification of thermophilic bacterial isolates by $16 S$ rRNA gene sequence homology

\begin{tabular}{lllll}
\hline Isolate & \multicolumn{2}{l}{ Sequence homology } & Phylum \\
\cline { 2 - 4 } & Closest species & Accession no. & $\begin{array}{l}\text { Per cent } \\
\text { homology }\end{array}$ & \\
\hline VCB1 & Bacillus tequilensis & MG098075 & 74 & Firmicutes \\
VCB2 & Bacillus tequilensis & MG098076 & 99 & Firmicutes \\
VSDB4 & Bacillus tequilensis & MG027696 & 99 & Firmicutes \\
KBFB2 & Bacillus licheniformis & MG028595 & 99 & Firmicutes \\
KBFB3 & Bacillus licheniformis & MG028594 & 99 & Firmicutes
\end{tabular}

a Species identified based on 16S rRNA gene sequence similarity

b Per cent similarity of the sequence in BLAST analysis 


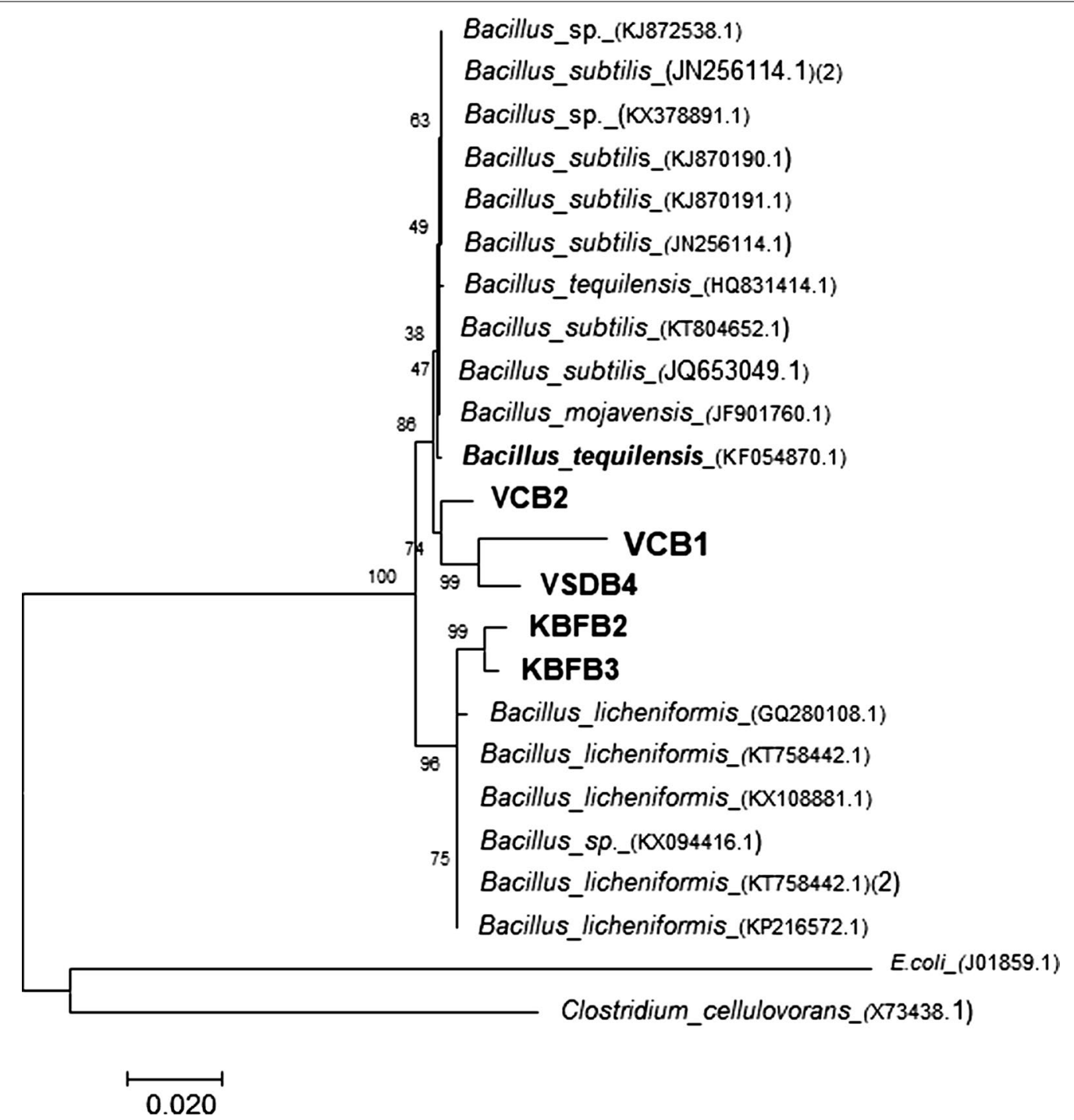

Fig. 3 Phylogenetic dendogram based on the 16S rDNA sequences of isolates and reference sequences retrieved from genbank. The phylogenetic tree was constructed based on neighbourhood joining method ( $\mathrm{NJ}$ ) using Mega 7.0 software with a bootstrap value of 0.020

units. All the isolates produced a significant amount of FPA until $48 \mathrm{~h}$ which declined thereafter. Among the isolates, B. tequilensis VCB1 and B. tequilensis VCB2 showed maximum activities of 3.38 and $2.8 \mathrm{IU} \mathrm{ml}^{-1}$ at $48 \mathrm{~h}$ followed by B. tequilensis VSDB4 $\left(2.72 \mathrm{IU} \mathrm{ml}^{-1}\right)$ (Fig. 5a).

\section{Endoglucanase (endo-1,4- $\beta$-glucanase;} carboxymethylcellulase; EC3.2.1.4)

The promising thermophilic isolates were able to produce endoglucanase utilizing CMC as a substrate. A maximum titre of $4.81 \mathrm{IU} \mathrm{ml}^{-1}$ was observed with $B$. licheniformis KBFB3 followed by B. tequilensis VSDB4 $\left(4.28 \mathrm{IU} \mathrm{ml}^{-1}\right)$ at $24 \mathrm{~h}$. The endoglucanase activity of other thermophilic isolates was in the range of 3.02 to $3.97 \mathrm{IU} \mathrm{ml}^{-1}$ (Fig. 5b), which however declined gradually later beyond $24 \mathrm{~h}$ irrespective of all the isolates.

\section{Exoglucanase (avicelase)}

Maximum exoglucanase activity was observed with $B$. tequilensis VSDB4 $\left(0.061 \mathrm{IU} \mathrm{ml}^{-1}\right)$ followed by B. tequilensis VCB1 $\left(0.042 \mathrm{IU} \mathrm{ml}^{-1}\right)$ and the rest of the isolates produced the same level of activity at $24 \mathrm{~h}$ of growth. A drop in the activity was noticed at $48 \mathrm{~h}$ in all the isolates and there was no significant difference among the isolates for exoglucanase activity. However, the enzyme activities were found to decline gradually after $24 \mathrm{~h}$ (Fig. $5 \mathrm{c}$ ). 


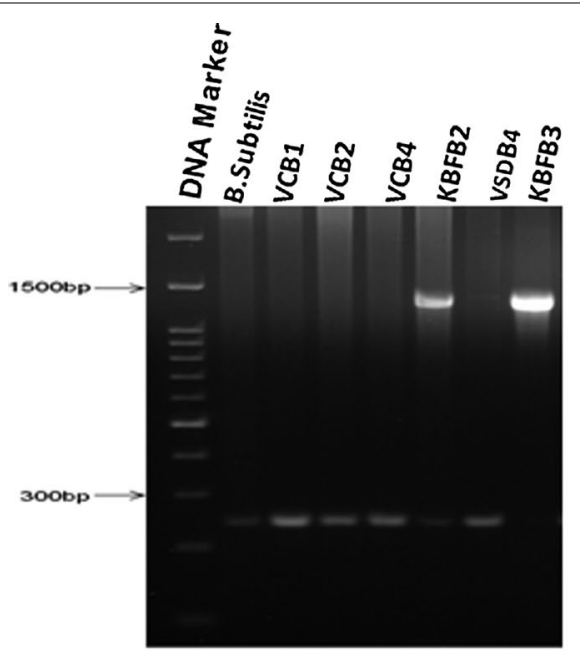

a $\mathrm{Cels}$

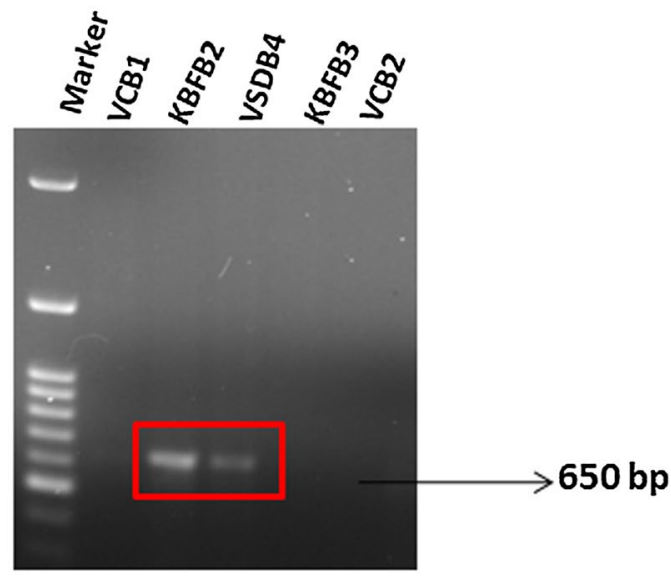

b $\mathrm{CelB}$

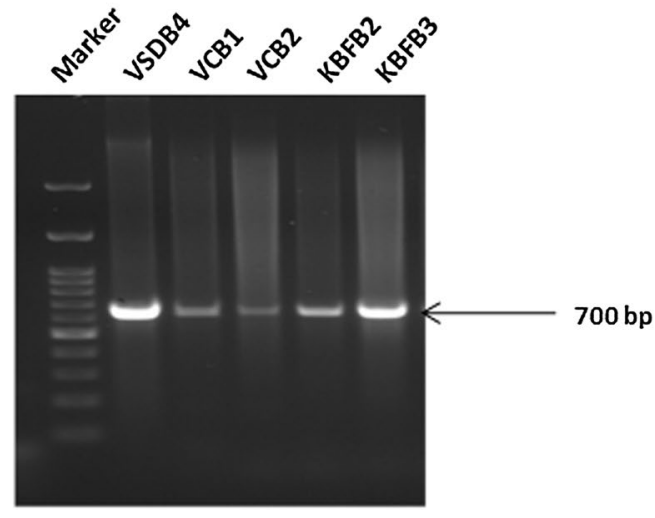

C $x \ln B$

Fig. 4 PCR based confirmation of cellulolytic and xylanolytic activity by bacterial isolates. Further, the thermophilic bacterial isolates were confirmed for cellulolytic and xylanolytic activity using specific primers for cellulase (celS), cellulose binding domain (celB) and xylanase (xInB). a Cel $S \mathbf{b} \operatorname{cel} B \mathbf{c} x \ln B$

\section{Aryl $\beta$-glucosidase (cellobiase; EC3.2.1.21)}

The cellobiase activity of the five thermophilic bacterial isolates grown in production media containing CMC and cellobiose $(1 \%)$ were assayed using cellobiose and o-nitrophenyl- $\beta$-D-glucopyranoside (pNPG) as substrates. The cellobiase activity registered a steady increase from $24 \mathrm{~h}$ and reached a maximum at $48 \mathrm{~h}$, although declined thereafter (Fig. 5d, e).

The cellobiase activity for $\mathrm{CMC}$ grown isolates was observed to be in the range of 0.210 to $0.705 \mathrm{IU} \mathrm{ml}^{-1}$ at $48 \mathrm{~h}$ registering a maximum by $B$. licheniformis KBFB3 $\left(0.705 \mathrm{IU} \mathrm{ml}^{-1}\right)$ followed by $B$. licheniformis KBFB2 $\left(0.562 \mathrm{IU} \mathrm{ml}^{-1}\right)$ and B. tequilensis $\mathrm{VCB} 2\left(0.464 \mathrm{IU} \mathrm{ml}^{-1}\right)$.

On the other hand, $\beta$-glucosidase activity on pNPG for cellobiose grown cultures was found to be higher than those grown in medium with CMC. Enzyme activity ranged from 2 to $23 \mathrm{IU} \mathrm{ml}^{-1}$ with a maximum titre recorded at $48 \mathrm{~h}$. However, thereafter the enzyme activity recorded a declining trend. Among the isolates, $B$. tequilensis $\mathrm{VCB} 1$ registered significant BGL activity of $23 \mathrm{IU} \mathrm{ml}^{-1}$ followed by B. tequilensis VCB2 $\left(20.4 \mathrm{IU} \mathrm{ml}^{-1}\right)$ and B. licheniformis KBFB2 $\left(11.44 \mathrm{IU} \mathrm{ml}^{-1}\right)$.

\section{Kinetic analyses of endoglucanase}

The apparent kinetic parameters $\left(\mathrm{V}_{\max }\right.$ and $\left.\mathrm{K}_{\mathrm{m}}\right)$ of the cellulase were determined by varying the $\mathrm{CMC}$ concentration from 1 to $5 \%$ corresponding to 38 to $190 \mathrm{mM}$ in $50 \mathrm{mM}$ sodium citrate buffer ( $\mathrm{pH} 5.0$ ). The Michaelis-Menten plot (Additional file 2: Fig. S1) showed that maximum best fit values of $\mathrm{K}_{\mathrm{m}}$ and $\mathrm{V}_{\max }$ for the elite cellulolytic bacterial isolates (Bacillus sp.) under the study had fallen in the range of 44.20 to $111.5 \mathrm{~m} \mathrm{Mol}$ and 5.34 to $19.73 \mu \mathrm{mol} \mathrm{min}{ }^{-1}$, respectively registering 


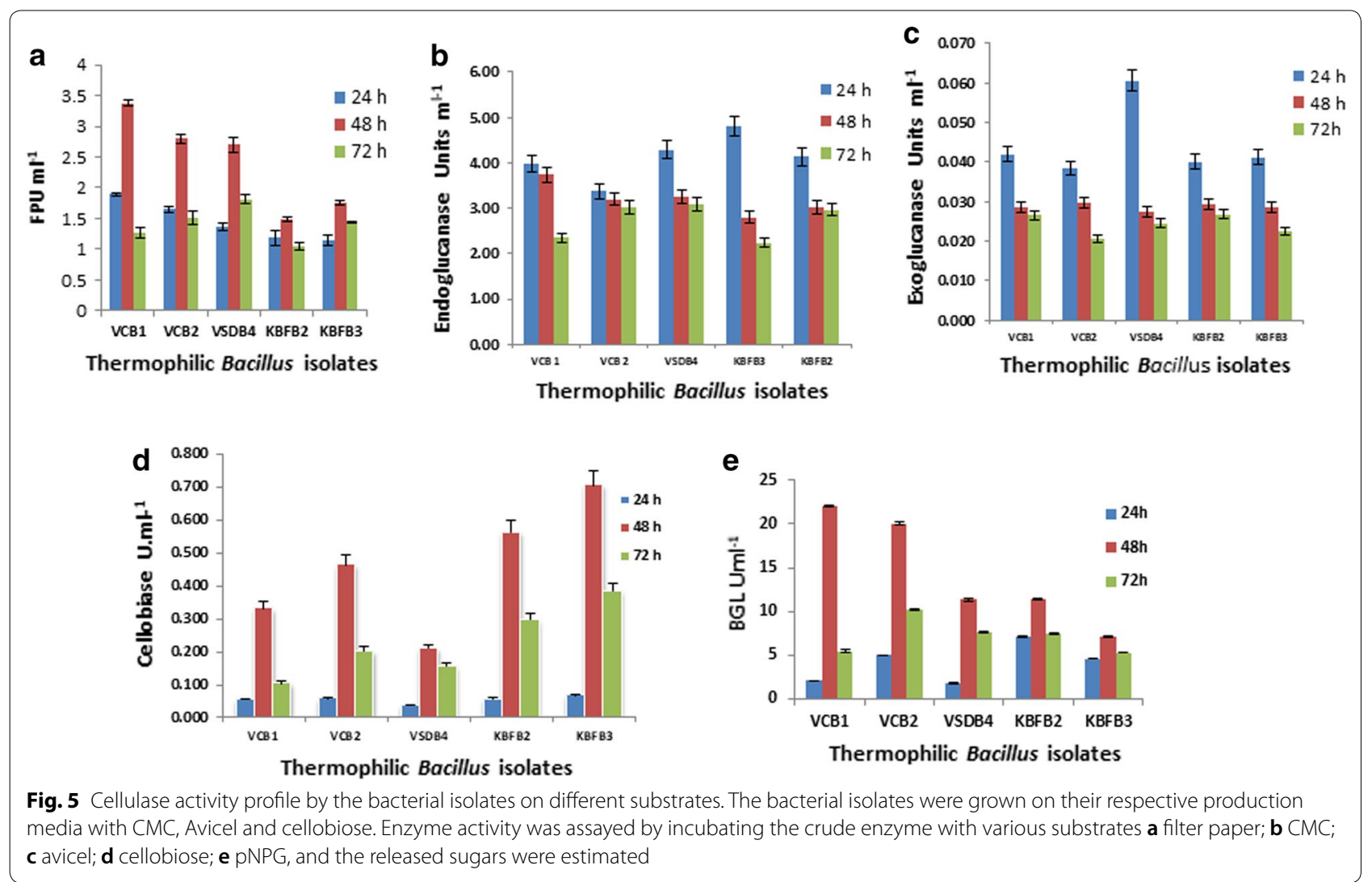

maximum $\mathrm{K}_{\mathrm{m}}$ and $\mathrm{V}_{\max }$ values by $B$. licheniformis KBFB3 compared to other isolates (Additional file 1: Table S2). Hence, it is evident from the study that the enzyme endoglucanase of $B$. licheniformis KBFB3 showed maximal hydrolytic efficiency for CMC with the highest $\mathrm{Km}$ and $\mathrm{Vmax}$ values. Hence, for further characterization of endoglucanases, $B$. licheniformis KBFB3 was considered.

\section{Partial purification and characterization of GHs}

The partially purified cell-free culture supernatant of the selected thermophilic biocatalysts which showed significant titre value for all the cellulases $(n=4)$ was analyzed by SDS-PAGE (Fig. 6). From Fig. 6a it was inferred that bands corresponding to the cellulase proteins migrated with molecular mass $75 \mathrm{kDa}$. Zymogram analysis with activity staining for the said isolates was also carried

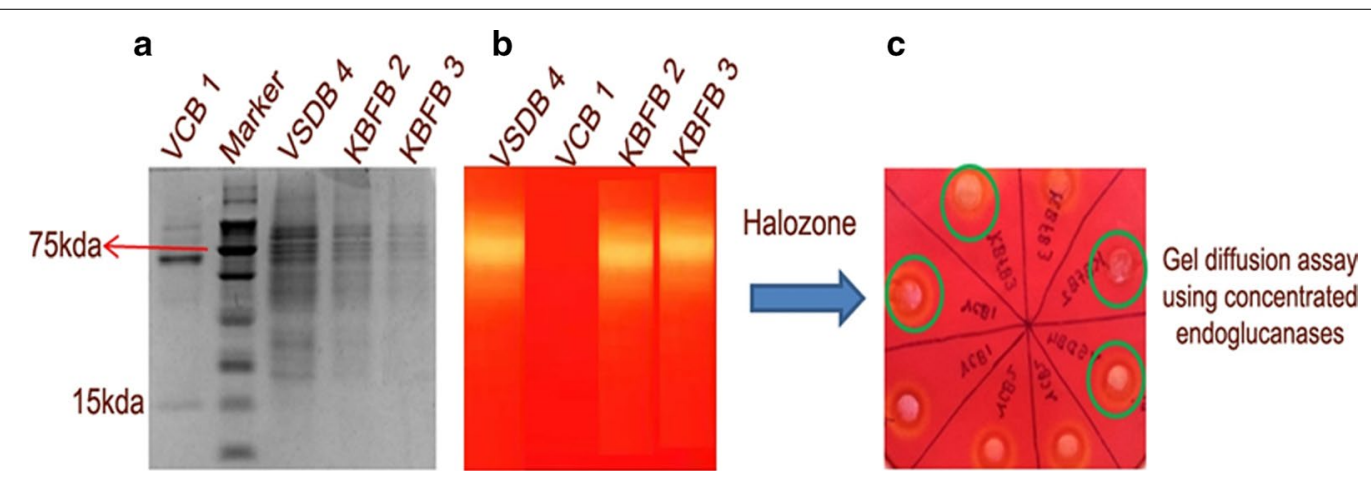

Fig. 6 SDS PAGE and zymogram analysis showing cellulolytic activity. a SDS profile of endoglucanase by the promising thermophilic isolates grown on culture media with $C M C ; \mathbf{b}$ invitro endoglucanase activity in polyacrylamide gel with CMC; $\mathbf{c}$ halo zones showing endoglucanase activity on $\mathrm{CMC}+$ agarose plates stained with CongoRed 
out parallely and the Congo red staining followed by destaining using $1 \mathrm{M} \mathrm{NaCl}$ showed clear halo formation (Fig. 6b). In addition, the extracellular endoglucanase on agarose plate with $1 \% \mathrm{CMC}$ also confirmed the degradation of $\mathrm{CMC}$ by forming a yellow colour halo around the well except for VCB1 (Fig. 6c).

The partially purified endoglucanase from $B$. licheniformis KBFB3 had the specific activity of $16.3 \mathrm{U} \mathrm{mg}^{-1}$ with 2.34-fold purity (Additional file 1: Table S3). The promising strains $B$. tequilensis VCB1 and B. licheniformis KBFB3 were submitted in NAIMCC under the accession no. TB2589 and TB2590 respectively.

\section{Characterization of purified enzyme} Effect of temperature and $p H$ on endoglucanase activity of $B$. licheniformis KBFB3

Profiles of specific enzyme activity obtained using CMC as a substrate, over a range of $\mathrm{pHs}$ and temperatures, are shown in Fig. 7. The specific activity of the enzyme increased from 45 to $70{ }^{\circ} \mathrm{C}$ and declined thereafter. But the endoglucanase or endoglucanase activity sustained up to $80{ }^{\circ} \mathrm{C}$. Similarly, in the case of $\mathrm{pH}$, the specific activity was maximum in Na-acetate buffer with $\mathrm{pH} 4.5$ followed by $\mathrm{pH} 7.0$ and $\mathrm{pH} 8.0$ compared to minimal activity at $\mathrm{pH} 3.0$ as well as at $\mathrm{pH} 9.5$. There was a sharp linear decline in endoglucanase activity beyond $\mathrm{pH} 7$ and $76 \%$ of activity is retained at $\mathrm{pH} 8.5$. In general, Tris and ammonia buffers with $\mathrm{pH} 8.5$ and 9.5 were found to inhibit endoglucanase activity of $B$. licheniformis KBFB3.
Effect of metal ions on endoglucanase activity

Bacillus licheniformis KBFB3 endoglucanase was activated by $5 \mathrm{mM} \mathrm{Ca}^{2+}$ and $\mathrm{K}^{1+}$ but inhibited by all other metal ions to a significant level. The results showed that endoglucanase exhibited maximum relative activity (108.2 and $112.4 \%$ in the presence of calcium and potassium ions whereas the relative activity with $\mathrm{Na}^{1+}$ was almost on par with $\mathrm{K}^{1+}$ ions. Endoglucanase activity was inhibited by $\mathrm{Zn}^{2+}$ and $\mathrm{Cu}^{2+}$ which registered 76 and $82 \%$ relative activity (Fig. 8).

\section{Effect of inhibitors on endoglucanase activity}

The effect of various inhibitors on endoglucanase stability was also investigated and the results are depicted in Fig. 8. The relative activity with $5 \mathrm{mM}$ EDTA, $\beta$-mercaptoethanol, and DTT was retained at 117.0, 101.4 and $114.0 \%$ respectively whereas urea slightly inhibited the activity (94\%).

\section{Effect of surfactants, detergents and oxidizing agents on endoglucanase activity}

The enzyme was extraordinarily stable in the presence of non-ionic surfactants like triton 100 and tween-80 with the relative activity of 92 and $94.7 \%$, respectively (Fig. 8). Also, the detergent SDS inhibited the activity to a tune of $15 \%$ and retained the activity at $85 \%$ against control. Among the two oxidizing agents experimented, the endoglucanase activity was activated in the presence of sodium hypochlorite and $\mathrm{H}_{2} \mathrm{O}_{2}$ with relative activities 112.4 and $86.9 \%$ at $0.5 \%$ concentration.
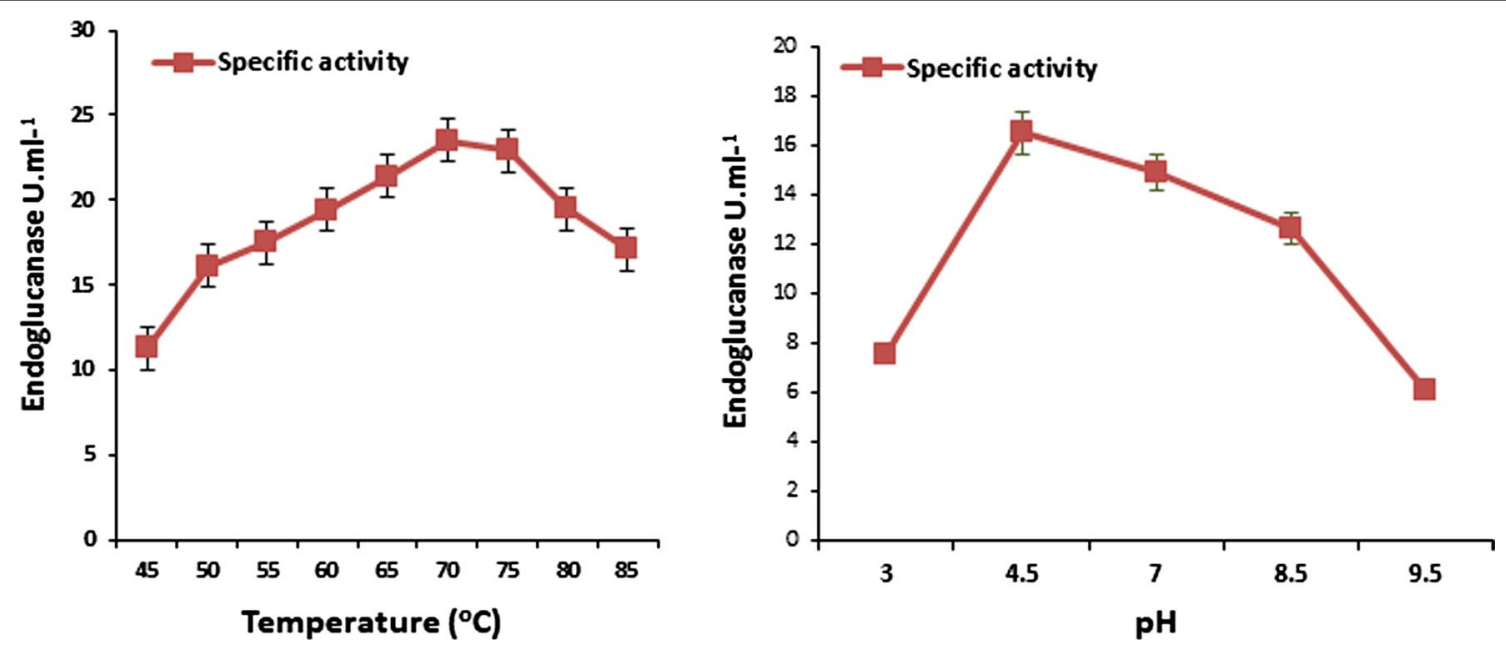

Fig. 7 Effect of temperature and $\mathrm{pH}$ on endoglucanase activity for the strain Bacillus licheniformis KBFB3. The optimum $\mathrm{pH}$ and temperature for endoglucanase activity for the best isolate Bacillus licheniformis KBFB3 was determined by growing it in production media amended with CMC $1 \%$ in the different range of temperature and $\mathrm{pH}$ 

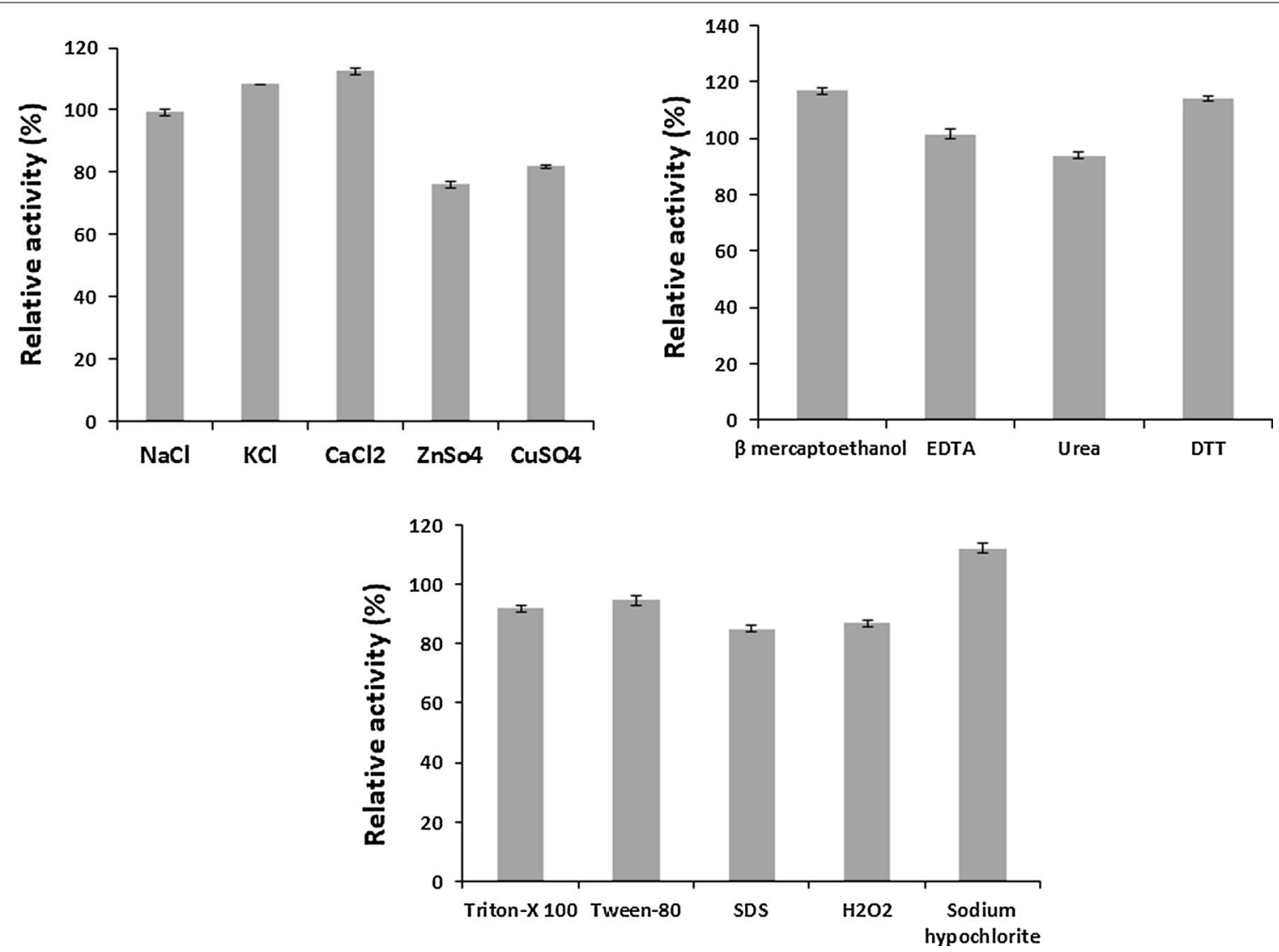

Fig. 8 Effect of metal ions, inhibitors, surfactants, detergents and oxidizing agents on endoglucanase activity. Endoglucanase activity was determined at $70^{\circ} \mathrm{C}$ at pH 7.0 in the presence of various metal ions, inhibitors, surfactants, detergents and oxidizing agents. After a period of $1 \mathrm{~h}$ pre-incubation, endoglucanase activity was assayed. The enzyme activity without pre-incubation with metal ions, inhibitors, surfactants, detergents and oxidizing agents was taken as $100 \%$. Mean standard deviation for all the values is $\pm 5.0 \%$

\section{Discussion}

Cellulase producing microbes are largely isolated from adverse environments and the majority of them are found to elaborate alkaline hydrolytic extracellular enzymes. However, so far only a few kinds of microbes with multifunctional enzyme complex have been reported (Zhang and Lynd 2004). Exploring lignocellulose rich samples, in which natural thermophilic biomass deconstruction occurs, might serve as a fruitful source for isolation of new thermophilic cellulase and xylanase producing candidates. Earlier studies adopted to switch grass and employed substrate specific enrichment technique for isolation of cellulose and hemicelluloses degrading bacteria (Eichorst et al. 2014). In the present study, thermophilic bacteria were isolated from the lignocellulosic rich substrates viz, pine needles, PABA, vanillin, acid extracted lignin, lignin extracted from black liquor, banana fibre, grapes, paddy straw, crop residue, corncob and saw dust which contained $25-50 \%$ cellulose, $37-50 \%$ hemicelluloses and 5-15\% lignin. The enrichment of the lignocellulosic substrates at thermophilic hot springs yielded 38 thermophilic potential bacterial isolates that produce hydrolytic enzymes. Among the hot springs selected for study, Manikaran registered $65.79 \%$ of total thermophiles followed by Kalath $(23.68 \%)$ and Vasist $(10.53 \%)$. Among the 38 thermophilic bacteria isolated, $63.15 \%$ (24 isolates) of total bacteria exhibited cellulase cum xylanase activities while $20.83 \%$ of bacterial isolates showed only cellulase activity. These results clearly indicate a rich diversity of thermophilic bacteria producing glycosyl hydrolases type of enzymes in hot springs of Himachal Pradesh.

Bacillus sp. is gram-positive bacteria with a high level of extra cellular enzyme production capacity which has attracted its application in many industries. Cellulase and xylanase enzyme production by several Bacillus species has been reported by several workers (Heck et al. 2002; Bhalla et al. 2013; Sharma et al. 2015). Several cellulases with optimum activity at $40{ }^{\circ} \mathrm{C}$ have been identified, while the enzymatic hydrolysis at $\leq 50{ }^{\circ} \mathrm{C}$ exhibit slower hydrolysis rates and often incomplete. This problem can be overcome by thermostable enzymes isolated 
from thermophilic microbes growing at $50-80{ }^{\circ} \mathrm{C}$. In this study, five cellulase cum xylanase producing thermophilic bacterial isolates namely $B$. tequilensis (VCB $1, \mathrm{VCB} 2$ and VSDB4) and B. licheniformis (KBFB2 and KBFB3) were isolated from different cellulose and hemicelluloses rich substrates, banana fibre, saw dust and corn cob and selected based on preliminary plate assay. Maximum endo and exoglucanase activity were obtained in B. licheniformis KBFB3 $\left(4.81 \mathrm{IU} \mathrm{ml}^{-1}\right)$ and B. tequilensis VSDB4 (0.061 IU ml $\left.{ }^{-1}\right)$ isolated respectively from banana fibre and sawdust enriched sample, but low in B. tequilensis VCB2, isolated from corncob enrichment. Optimal cellulase activities at $\mathrm{pH} 6$ after incubation at $40{ }^{\circ} \mathrm{C}$ were reported in Bacillus circulans and Bacillus subtilis (Otajevwo and Aluyi 2011). Thermostable endoglucanase activity was reported in Bacillus amyloliquefaciens DL-3 which could maintain $40 \%$ of its activity at broad $\mathrm{pHs}$ ranging from $\mathrm{pH} 4.0$ to $\mathrm{pH} 9.0$ after $20 \mathrm{~h}$ incubation at $50{ }^{\circ} \mathrm{C}$ (Lee et al. 2008; Sharma et al. 2015).

On the other hand, maximum FP activity $\left(3.38 \mathrm{IU} \mathrm{ml}^{-1}\right)$ was observed at $48 \mathrm{~h}$ in $B$. tequilensis VCB1 isolated by corn cob enrichment from Vasist. Similarly, B. licheniformis KBFB3 also showed maximum cellobiase activity. It was observed that B. licheniformis KBFB3 isolated from the banana fibre is endowed with multifunctional GH enzymes which could be attributed to the nature of substrates enriched. Even though the B. licheniformis KBFB2 was same as that of $B$. licheniformis KBFB3, both differed entirely in their GH profile. While B. tequilensis VSDB4 recorded good exoglucanase activity, B. tequilensis VCB1 had maximum FP activity. In this case, the substrate might have played a major role in determining the activity of a particular class of GHs. Natural fibers are generally hydrophilic in nature as they are derived from lignocellulose-containing strongly polarized hydroxyl groups (Zhang and Lynd 2004), and the high cellulose (64\%) hemicellulose and lignin contents in the banana fibre attributes to efficient microbes with multiple $\mathrm{GH}$ functions (Eichorst et al. 2014).

Interestingly, the Bacillus species identified were able to produce cellobiase activity (aryl $\beta$-glucosidase) when they were grown in CMC (carboxy methyl cellulose). Thus, it was noted that $B$. licheniformis KBFB3 and $B$. licheniformis KBFB2 showed remarkable cellobiase production of 0.705 and $0.562 \mathrm{IU} \mathrm{ml}^{-1}$ at $48 \mathrm{~h}$. For cellulosegrown organisms, there was more aryl II $\beta$-glucosidase than aryl III $\beta$-glucosidase. With growth on cellobiose, aryl III $\beta$-glucosidase increased and it did not hydrolyze carboxymethyl cellulase while hydrolyzing cellobiose. Thus it seems that during growth on a particular substrate (cellulose or cellobiose) those enzymes that are necessary for its breakdown are located more externally. Endoglucanase was more external in Bacillus sp. growing on the cellulosic substrate than those growing on cellobiose. This is in accordance with the studies of Ramasamy and Verachtert (1980) while localizing the cellulase components in Pseudomonas sp. The cell-bound aryl II $\beta$-glucosidases of $B$. licheniformis KBFB3 and $B$. licheniformis KBFB2 has to be elucidated. Prolonged incubation after $48 \mathrm{~h}$ brought about a decline in the enzyme activity and biomass conversion which might probably due to the consequence of random lethal events, including cellular fragmentation in the death phase and release of intracellular protease into the fermentation broth (Papagianni et al. 2002).

The PCR amplicons of Endoglucanase (CMCase) region $(\mathrm{CelS})$ of about 250 bp for B. tequilensis (VCB1, VCB2 and VSDB4) and Bacillus subtilis VCB4 which served as positive control and $1300 \mathrm{bp}$ for B. licheniformis (KBFB2 and KBFB3) further confirms the presence of cellulase encoding operons in all the isolates. The presence of cellulose binding domain was further evident by the amplification of $c e l B$ gene $(650 \mathrm{bp})$ in $B$. licheniformis KBFB2 and KBFB3. Using Ba_EN1 primer, amplification of about 250 bp cellulase genes in B. subtilis and cellulose binding domain of 650 bp fragments in Bacillus sp. was reported earlier by Bischoff et al. (2006) and Hussain et al. (2011) respectively.

Further characterization of partially purified endoglucanases (CMCase) from the thermophilic Bacillus sp. on SDS PAGE revealed 69 and $15 \mathrm{kDa}$ fragments which were confirmed later by activity staining. This is compatible with the size of EGA reported by Bacillus sp Ac-1 (67 K Da) by Li et al. $(2006,2008)$. The multiple banding patterns observed with EGA might be due to cytoplasmic endoglucanases, periplasmic endoglucanases or aryl- $\beta$ glucosidase II. In the present studies, endoglucanases were extracellular which is testified by the hydrolytic activity in agarose wells with CMC. Thus for growth on cellulose, the cell bound endoglucanase might have been more extracellular in localization.

It is evident from the kinetics study that the reaction rate $(\mathrm{v})$ increases as the substrate $[\mathrm{S}]$ increases. However as $[\mathrm{S}]$ gets higher, the enzyme becomes saturated with the substrate and the rate reaches $\mathrm{V}_{\max }$, the enzymes maximum rate. The isolate $B$. licheniformis KBFB3 had high-

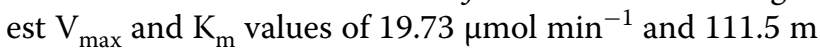
Mol to respectively for substrate concentration of $4 \%$ or $150 \mathrm{mM}$. Higher $\mathrm{Km}$ values reflect lower affinity between substrate and enzyme, indicating that the endoglucanase secreted by $B$. licheniformis KBFB3 had lower affinity for CMC than the B. tequilensis VSDB4 enzyme. In this study, the $\mathrm{K}_{\mathrm{m}}$ for CMC was determined by assaying the endoglucanases using a cell-free culture supernatant which was partially purified with 70 to $80 \%$ ammonium sulfate. The literature suggests that the kinetic behaviour 
of cellulases is affected in the presence of other proteins (or substances) in the medium (Cascalheira and Queiroz 1999).

Partially purified endoglucanase obtained from the culture supernatant of promising elite isolate, $B$. licheiformis KBFB3 showed maximum specific activity (13.0 $\mathrm{IU} \mathrm{mg}^{-1}$ ) compared to that reported by Li et al. (2006) and Singh and Kaur (2012) which was slightly less than the specific activity of purified enzyme activity obtained from Bacillus sp. However, further purification by ion exchange and gel filtration chromatographic would improve the specific activity of $B$. licheiformis KBFB3 as mentioned in previous reports. Characterization of endoglucanase from $B$. licheniformis KBFB3 showed that the optimal $\mathrm{pH}$ range is 4.5-7.0 and $70{ }^{\circ} \mathrm{C}$, and the enzyme specific activity indicated a steady linear decrease thereafter. Even at alkaline $\mathrm{pH}$ of 8.5, endoglucanase of KBFB3 retained about $76 \%$ of residual specific activity. The thermal stability curves indicate that the enzyme was stable at $70{ }^{\circ} \mathrm{C}$, which remained sustained till $80{ }^{\circ} \mathrm{C}$, though declined sharply thereafter. B. licheniformis KBFB3 retained its specific activity up to $\mathrm{pH} 8.5$ although for the other reported bacterial cellulases, the optimum $\mathrm{pH}$ of the crude cellulase was pH 5.0 (Mawadza et al. 2000). This observation indicates and endorses the thermo- and alkaline tolerant nature of endoglucanase of $B$. licheniformis KBFB3.

Thermal and alkaline/pH stability is another additional important characteristic of industrial enzymes. Thermophilic cellulases are required for many industrial applications, and only a few reports on thermophilic cellulases from mesophilic organisms are available (Li et al. 2006; Sangeeta et al., 2013; Bischoff et al. 2006). Endoglucanase from Bacillus sp. DUSEL R7 was active at $75^{\circ} \mathrm{C}$ and has a half-life of $552 \mathrm{~h}$ at $60^{\circ} \mathrm{C}$ (Rastogi et al. 2010). The mining of efficient thermotolerant Glycosyl hydrolases yielded a multifarious thermophilic isolate B. licheniformis KBFB3 with superior endoglucanases, beta-glucosidases and xylanases (data not shown). The hyper xylanase activity of B. licheniformis KBFB3 has not been discussed here and evaluation of its saccharification potential on different substrates is underway. Results of the present study evidence the suitability of the thermostable and alkalitolerant endoglucanases of $B$. licheniformis KBFB3 for possible efficient application in enzymatic hydrolysis of various lignocellulosic biomasses.

Endoglucanase activity was activated by $5 \mathrm{mM} \mathrm{Ca}{ }^{2+}$ and $\mathrm{K}^{1+}$ ions and $\mathrm{Na}^{1+}$ has no adverse effect. Gaur and Tiwari (2015) had also reported that $\mathrm{Ca}^{2+}, \mathrm{Na}^{1+}$ and $\mathrm{Mg}^{2+}$ ions strongly stimulated cellulase activity. Endoglucanase activity was inhibited by $\mathrm{Zn}^{2+}$ and $\mathrm{Cu}^{2+}$ metal ions. Similar results were reported for Bacillus amyloliquefaciens DL-3 (Lee et al. 2008) and Bacillus vallismortis RG-07 (Gaur and Tiwari 2015). The inhibition of endoglucanase activity by $\mathrm{Zn}^{2+}$ and $\mathrm{Cu}^{2+}$ ions could be due to decreased metalloenzyme activity resulted in the competition between exogenous cations and protein associated cations.

The endoglucanase of Bacillus licheniformis KBFB3 is stable in the presence of EDTA, $\beta$-mercaptoethanol, and DTT at a concentration of $5 \mathrm{mM}$. Similarly, Gaur and Tiwari (2015) reported that Bacillus vallismortis RG-07 retained activity with $10 \mathrm{mM}$ EDTA, $\beta$-mercaptoethanol and DTT. The inhibition of endoglucanase activity by urea might be due to a slight degree of interaction with the SH group. However, DTT can reduce the disulfide bonds and re-nature their activity. The active site of endoglucanase of $B$. licheniformis KBFB3 may contain SH group as reported by Gaur and Tiwari (2015) in Bacillus vallismortis RG-07. Wang et al. (2008) have reported that SDS and tween-80 moderately inhibited cellulase activity whereas Gaur and Tiwari (2015) observed that cellulase of Bacillus vallismortis RG-07 was highly stable with $1 \%$ SDS retaining $95 \%$ of activity. In the present study also the endoglucanase of $B$. licheniformis KBFB3 is moderately resistant to SDS at $0.5 \%$ and the effects of other detergents need to be elucidated.

Furthermore, the endoglucanase activity was substantially stable with oxidizing agents at a concentration of $0.5 \%$. Similarly, Gaur and Tiwari (2015) reported that higher concentrations of oxidizing agents (1.0\%) decreased the stability of cellulase except for sodium hypochlorite whereas lower concentrations (0.1\%) enhanced the activity. This suggests that the endoglucanase of B. licheniformis KBFB3 is moderately tolerant to oxidizing agents and detergents and prove its potential applications in detergent formulations.

In spite of the fact that cellulase and xylanase are widely isolated from several organisms, it is the bacteria with higher growth rate produce enzyme complements which are stable at extreme temperature and $\mathrm{pH}$. This particular feature gives an added advantage of utilizing bacterial cellulase and xylanase in simultaneous saccharification and fermentation process of waste recycling and biofuel production. The study further opens of new horizons of knowledge to look beyond unifunctional enzymes to multifunctional thermostable glycosyl hydrolases which have immense implications in biomass valorization to abate global energy crisis and environmental conservation. Nevertheless, research is underway worldwide to optimize cellulase production, which should facilitate efforts in the development of a robust and cost-effective process for the bioprocessing of cellulosic biomass to biofuels and value-added bioproducts. The present study has contributed significantly to the enhancement of existing knowledge on multifunctional biocatalysts from thermophilic bacteria from hot springs and holds the key 
for future development of ideal thermostable enzymes for industrial applications particularly valorization of biomass.

\section{Additional files}

Additional file 1: Table S1. Gene specific primers for screening various Glycosyl hydrolases. Table S2. Kinetics of EGA as predicted by MichaelisMenten model. Table S3. Summary of purification of Endoglucanase from B. licheniformis KBFB3.

Additional file 2: Fig. S1. Kinetics of endoglucanase (activity on different concentrations of substrate (CMC). The $\mathrm{Km}$ and $\mathrm{V}_{\max }$ values for the five isolates for endoglucanase were calculated by Michelis Menten plots.

\section{Authors' contributions}

Author US has received research grants from DBT, India and conceptualized the idea. ST executed most of the experiments, KS initiated the isolation part and BJ assisted in PCR work. KNS and OTP are collaborators of the project. All authors read and approved the final manuscript.

\section{Author details}

1 Department of Agricultural Microbiology, Tamil Nadu Agricultural University, Coimbatore 641003, India. ${ }^{2}$ Boreskov Institute of Catalysis (BIC), Siberian Branch of the Russian Academy of Sciences, Novosibirsk, Russia.

\section{Acknowledgements}

The authors are grateful to Dr. M. Chandrasekaran, Emeritus Scientist, Department of Biotechnology, Cochin University for his support in manuscript editing.

\section{Competing interests}

The authors declare that they have no competing interests.

\section{Availability of data and materials}

The nucleotide sequences of all the thermophilic bacterial isolates were submitted in GenBank (National Center for Biotechnology Information) and the accession numbers were mentioned in the manuscript.

\section{Consent for publication}

Not applicable.

\section{Ethical approval and consent to participate}

This article does not contain any studies with animals performed by any of the authors.

\section{Funding}

This work was supported by the grant from DBT funded Indo-Russia project (No. DBT/IC-2/Indo-Russia/2014-16/04) and the research work was executed at Biocatalysts lab, Tamil Nadu Agricultural University, Coimbatore, India.

\section{Publisher's Note}

Springer Nature remains neutral with regard to jurisdictional claims in published maps and institutional affiliations.

Received: 6 June 2018 Accepted: 26 September 2018

Published online: 15 October 2018

\section{References}

Annamalai N, Thavasi R, Jayalakshmi S, Balasubramanian T (2009) Thermostable and alkaline tolerant xylanase production by Bacillus subtilis isolated from marine environment. Ind J Biotechnol 8:291-297
Bassat AB, Zeikus JG (1981) Thermobacteroides acetoethylicus gen. nov. and spec. nov., a new chemoorganotrophic, anaerobic, thermophilic bacterium. Arch Microbiol 128:365-370

Bhalla A, Bansal N, Kumar S, Bischoff KM, Sani RK (2013) Improved lignocellulose conversion to biofuels with thermophilic bacteria and thermostable enzymes. Bioresour Technol 128:751-759

Bischoff KM, Rooney AP, Li XL, Liu S, Hughes SR (2006) purification and characterization of a family 5 endoglucanase from a moderately thermophilic strain of Bacillus licheniformis. Biotechnol Lett 28:1761-1765

Blumer-Schuette SE, Kataeva I, Westpheling J, Adams MW, Kelly RM (2008) Extremely thermophilic microorganisms for biomass conversion: status and prospects. Curr Opin Biotechnol 19:210-217

Buckley M, Wall J (2006) Microbial energy conversion. Collogia report to American Society of Microbiology

Cascalheira J, Queiroz J (1999) Kinetic study of the cellobiase activity of Trichoderma reesei cellulase complex at high substrate concentrations. Biotechnol Lett 21:651-655

Dubois M, Gilles KA, Hamilton JK, Rebers PA, Smith F (1956) Colorimetric method for determination of sugars and related substances. Anal Chem 28:350-356

Eichorst SA, Joshua C, Sathitsuksanoh N, Singh S, Simmons BA, Singer SW (2014) Substrate-specific development of thermophilic bacterial consortia by using chemically pretreated switchgrass. Appl Environ Microbiol 80(23):7423-7432

Gaur R, Tiwari S (2015) Isolation, production, purification and characterization of an organic solvent thermostable alkalophilic cellulase from Bacillus vallismortis RG-07. BMC Biotechnol 15:19-30

Heck JX, Plinho F, Marco H, Ayub AZ (2002) Cellulase and xylanase production by isolated amazon Bacillus strains using soybean industrial residue based solid-state cultivation. Brazil J Microbiol 33:213-218

Hong J, Ye X, Zhang YHP (2007) Quantitative determination of cellulose accessibility to cellulase based on adsorption of a nonhydrolytic fusion protein containing cbm and gfp with its applications. Langmuir 23(25):12535-12540

Hussain MH, Chong NFM, Chan CSW, Safarina A, Husaini A (2011) Xylanase gene from a locally isolated bacterium. Malay Appl Biol 40(1):33-38

Kumar R, Wyman CE (2009) Effect of xylanase supplementation of cellulase on digestion of corn stover solids prepared by leading pretreatment technologies. Bioresour Technol 100:4203-4213

Laemmli UK (1970) Cleavage of structural proteins during the assembly of head of bacteriophage T4. Nature 15:227

Lee YJ, Kim BK, Lee BH, Jo Kl, Lee NK, Chung CH, Lee YC, Lee JW (2008) Purification and characterization of cellulase produced by Bacillus amyoliquefaciens DL-3 utilizing rice hull. Bioresource Technol 9:378-438

Li Y, Li J, Meng D, Lu J, Gu G, Mao Z (2006) Effect of pH, cultivation time and substrate concentration on the endoxylanase production by Aspergillus awamori ZH-26 under submerged fermentation using central composite rotary design. Food Technol Biotechnol 44:473-477

Li W, Zhang W, Yang M, Chen Y (2008) Cloning of the thermostable cellulase gene from newly isolated Bacillus subtilis and its expression in Escherichia coli. Mol Biotechnol 40:195-201

Liang Y, Feng Z, Yesuf J, Blackburn JW (2009a) Optimization of growth medium and enzyme assay conditions for crude cellulases produced by a novel thermophilic and cellulolytic bacterium, Anoxybacillus sp. 527. Appl Biochem Biotechnol 160:1841-1852

Liang Y, Yesuf J, Schmitt S, Bender K, Bozzola J (2009b) Study of cellulases from a newly isolated thermophilic and cellulolytic Brevibacillus sp. strain JXL. J Ind Microbiol Biotechnol 36:961-970

Limayem A, Ricke SC (2012) Lignocellulosic biomass for bioethanol production: current perspectives, potential issues and future prospects. Prog Energy Combust Sci 38:449-467

Mawadza C, Hatti-Kaul R, Zvauya R, Mattiasson B (2000) Purification and characterization of cellulases produced by two Bacillus strains. J Biotechnol $83: 177-187$

Nelson N (1944) A photometric adoption of the Somogyi method for the determination of glucose. J Biol Chem 153:315-380

Otajevwo FD, Aluyi HS (2011) Cultural conditions necessary for optimal cellulase yield by cellulolytic bacterial organisms as they relate to residual sugars released in broth medium. Modern App Sci 5(3):141-151

Papagianni M, Joshi N, Moo-Young M (2002) Comparative studies on extracellular protease secretion and glucoamylase production by free 
and immobilized Aspergillus niger cultures. J Ind Microbiol Biotechnol 29(5):259-263

Ramasamy K, Verachtert H (1980) Localization of cellulase components in Pseudomonas sp. isolated from activated sludge. J Gen Microbiol 117:181-191

Rastogi G, Muppidi RN, Gurram A, Adhikari KM, Bischoff SR, Hughes WA, Apel SS, Bang DJ, Dixon K, Sani RK (2009) Isolation and characterization of cellulose-degrading bacteria from the deep subsurface of the Home stake gold mine, Lead, South Dakota, USA. J Ind Microbiol Biotechnol 36:585-598

Rastogi G, Bhalla A, Adhikari A, Bischoff KM, Hughes SR, Christopher LP, Sani RK, Buckley M, Wall J (2010) Characterization of thermostable cellulases produced by Bacillus and Geobacillus strains. Bioresour Technol 101(22):8798-8806

Salem F, Ahmed S, Jamil A (2008) Isolation of a xylan degrading gene from genomic DNA library of a thermophilic fungus Chaetomium thetmophile ATCC 28076. Pak J Bot 40:1225-1230

Sangeeta P, Singh S, Yadav AN, Lata N, Saxena AK (2013) Phylogenetic diversity and characterization of novel and efficient cellulase producing bacterial isolates from various extreme environments. Biosci Biotechnol Biochem 77(7):1474-1480

Sharma A, Tewari R, Soni SK (2015) Application of Statistical approach for optimizing CMCase production by Bacillus tequilensis $\$ 28$ strain via submerged fermentation using wheat bran as carbon source. Int J Biol Biomol Agric Food Biotechnol Eng 9(1):76-86

Singh J, Kaur P (2012) Optimization of process parameters for cellulase production from Bacillus sp. JS14 in solid substrate fermentation using response surface methodology. Braz Arch Biol Technol 55:505-512
Tong CC, Cole ALJ (1982) Cellulase production by the thermophilic fungus, Thermoascus aurentiacus. Pertanika 5:255-262

Vincent VL, Passari AK, Joshi JB, Mishra VK, Singh BP, Uthandi S (2016) A novel triculture system for simultaneous enzyme production and hydrolysis of common grasses through submerged fermentation. Front Microbiol 7:447

Wang CM, Shyu CL, Ho SP, Chiou SH (2008) Characterization of a novel thermophilic, cellulose degrading bacterium Paenibacillus sp. strain B39. Lett Appl Microbiol 47:46-53

Weisberg WG, Barns SM, Pelletier BA, Lane DJ (1991) 16S ribosomal DNA amplification for phylogenetic study. J Bacteriol 173:697-703

Wood T, Bhat K (1988) Methods for measuring cellulase activities. In: Willis A, Wood STK (eds) Methods in enzymology, vol 160. Academic Press, New York, pp 87-112

Zambare V, Zambare A, Muthukumarappan K, Christopher LP (2011) Biochemical characterization of thermophilic lignocelluloses degrading enzymes and their potential for biomass bioprocessing. Inter J Energy Environ 2(1):99-112

Zhang YHP, Lynd LR (2004) Toward an aggregated understanding of enzymatic hydrolysis of cellulose: noncomplexed cellulase systems. Biotechnol Bioeng 88:797-824

Zhang YHP, Hong J, Ye X (2009) Cellulase assays. Methods Mol Biol 581:213-231

\section{Submit your manuscript to a SpringerOpen ${ }^{\circ}$ journal and benefit from:}

- Convenient online submission

- Rigorous peer review

- Open access: articles freely available online

- High visibility within the field

- Retaining the copyright to your article

Submit your next manuscript at $\boldsymbol{\nabla}$ springeropen.com 